\title{
DECRETO 24.645/1934: BREVE HISTÓRIA DA “LEI ÁUREA" DOS ANIMAIS
}

\author{
DECREE 24.645/1934: A BRIEF HISTORY OF THE BRAZILIAN “AUREA LAW" OF \\ ANIMALS
}

Recebido: 15.07.2019

Vicente de Paula Ataide Junior

Pós-doutor pela Universidade Federal da Bahia. Doutor pela Universidade Federal do Paraná (UFPR). Professor da Universidade Federal do Paraná (UFPR). Juiz Federal titular no Paraná.

E-MAIL: vicente.junior@ufpr.br

LATTES:

http:/ / lattes.cnpq.br/8067162391395637

ORCID: http://orcid.org/0000-0003-4995-9928
Aprovado: 02.03.2020

\author{
Thiago Brizola Paula Mendes \\ Mestrando em Direito pela Universidade \\ Federal do Paraná. Advogado. \\ E-MAIL: t.brizola@hotmail.com \\ LATTES: \\ http://lattes.cnpq.br/7029064171481475 \\ ORCID: https:/ / orcid.org/0000-0003-0687-5441
}

RESUMO: O propósito deste trabalho é apurar as origens históricas e as fontes materiais do Decreto 24.645, de 10 de julho de 1934, considerado o primeiro estatuto jurídico geral do Direito Animal brasileiro, além de evidenciar os seus usos práticos, na época em que foi editado, não apenas na defesa dos direitos animais, como também na defesa dos direitos humanos. Para tanto, utiliza-se da pesquisa histórica, a partir do levantamento das principais publicações e notícias realizadas em jornais naquele período, como também do cotejo com a legislação estrangeira que pode ter subsidiado a elaboração da proposta legislativa. Termina por certificar que este diploma legal permanece vigente e apto para fundamentar, além da ocorrência do crime de maus-tratos, a capacidade de ser parte dos animais não-humanos.

PALAVRAS-CHAVE: Direito Animal; crueldade contra animais; capacidade de ser parte dos animais; Decreto 24.645/1934.

\begin{abstract}
The purpose of this paper is to ascertain the historical origins and material sources of Decree 24.645 of July 10, 1934, considered the first general legal status of Brazilian Animal Law, in addition to highlighting its practical uses, at the time of its publication, not only in the defense of animal rights, but also in the defense of human rights. To do so, it uses historical research, based on the survey of the main publications and news from newspapers in that period, as well as the comparison with foreign legislation that may have subsidized the drafting of the legislative proposal. It ends by certifying that this legal diploma still remains valid and able to substantiate, in addition to the occurrence of the crime of mistreatment against animals, the standing for nonhuman animals.
\end{abstract}

KEYWORDS: Animal Law; cruelty to animals; standing for animals; Decree 24.645/1934. 
SUMÁRIO: 1 Introdução 2 A origem histórica da "Lei Áurea" dos animais 2.1 A UIPA e a apresentação da proposta de lei 2.2 A edição do Decreto 24.645/1934 2.3 A difusão do Decreto como "Lei Áurea" 3 Possíveis fontes materiais da proposta de lei da UIPA - a importância do Protection of Animals Act inglês de 19114 O Decreto na prática 4.1 O Decreto na proteção animal 4.2 O Decreto na proteção de direitos humanos 5 Vigência do Decreto 24.645/1934 e ineficácia da revogação via Decreto Presidencial 11/1991 6 Conclusão 7 Notas de Referência

\section{Introdução}

O propósito deste trabalho é apurar a história do Decreto 24.645, de 10 de julho de 1934 - primeiro estatuto jurídico, de caráter geral, do Direito Animal brasileiro ${ }^{1}$-, com o objetivo de demonstrar as suas origens, as influências e fontes materiais ${ }^{2}$ da sua elaboração, além dos seus impactos e usos práticos reais na época, não apenas na defesa dos direitos animais, como também dos direitos humanos.

O trabalho também traz elementos para certificar que tal diploma legal ainda está vigente e com aptidão para auxiliar na caracterização do crime de maus-tratos (art. 32, Lei 9.605/1998), além de caracterizar, no âmbito processual, a capacidade de ser parte dos animais não-humanos.

A pesquisa parte do pressuposto que o Brasil já conta com um Direito Animal positivado, como ramo jurídico autônomo. ${ }^{3}$ Sua base é constitucional, pois o art. 225, §1으, VII, parte final, da Constituição de 1988, ao estabelecer a regra da proibição da crueldade, reconhece implicitamente a senciência ${ }^{4}$ e a dignidade ${ }^{5}$ animais, consagrando os animais como titulares de direitos fundamentais. ${ }^{6}$

Esse comando constitucional é densificado, no plano federal, sobretudo pelo art. 32 da Lei 9.605/1998 (crime contra a dignidade animal) e pelo Decreto 24.645/1934.

De especial destaque e importância atual, o art. 2으, §3으 do Decreto 24.645/1934 confere expressamente aos animais a possibilidade de estarem em juízo, assistidos pelo Ministério Público, por seus substitutos legais ou pelos membros das sociedades protetoras dos animais, o que caracteriza a capacidade de ser parte dos animais não-humanos, inovando, de sobremaneira, o sistema processual brasileiro. ${ }^{7}$

Por isso se justifica o interesse no estudo desse peculiar e singular diploma normativo brasileiro.

Assim sendo, o artigo aborda a origem histórica do Decreto 24.645/1934, analisando como, em meados dos anos 1930, foi possível a aprovação de um regramento tão inovador que tutela os animais não-humanos em geral, considerados em si mesmos, sem qualquer alusão à sua função ecológica, e lhes concede a capacidade de ser parte em processos judiciais -, tantos anos antes do início do debate moderno acerca das questões ambientais ${ }^{8}$ e dos direitos animais. ${ }^{9}$

Para levantar essa história, optou-se, metodologicamente, por realizar pesquisa jornalística, a partir do acervo digital do jornal O Estado de S. Paulo e na Hemeroteca Digital da Fundação Biblioteca Nacional. Além disso, buscaram-se informações por meio de contato direto com a União Internacional Protetora dos Animais - UIPA, entidade que, à época, apresentou a proposta que veio a ser adotada, como Decreto, pelo então Presidente da República, Getúlio Vargas. 
Com a varredura, foram levantadas, ao todo, 117 publicações ou notícias com alguma referência ao Decreto 24.645/1934, datadas de 1934 a 2001.

Como o principal objetivo do trabalho é levantar as origens remotas do Decreto, a triagem das notícias concentrou-se no período entre 1934 e 1939, coletando-se e sistematizando-se 68 publicações. As outras 69 publicações, datadas de períodos posteriores a 1939, foram utilizadas na medida em que apresentassem informações relevantes para o traçado histórico de usos práticos do Decreto. Além das notícias, para o mesmo desiderato, foi analisada a ata da 136a Sessão do Conselho da UIPA, dado que apresenta relevantes pistas para o levantamento histórico das fontes materiais do Decreto 24.645.

Também é importante registrar, no objetivo sempre presente de ampliar a pesquisa de dados, que foram realizadas buscas no Sistema de Informações do Arquivo Nacional - SIAN e formalizados pedidos ao Sistema de Informação ao Cidadão, endereçados ao Senado Federal, à Presidência da República e ao Ministério da Agricultura. No entanto, nenhuma dessas solicitações teve resultado frutífero.

Tendo em conta referências obtidas por meio das notícias jornalísticas coletadas e analisadas, também será apresentado um breve exame das legislações estrangeiras que, de alguma forma, foram utilizadas como fonte de inspiração para a redação da proposta de lei.

O trabalho também inclui exemplos, tirados dos jornais da época, de como os dispositivos do Decreto foram efetivados ao longo dos anos, tanto por autoridades públicas, quanto pela sociedade civil, para a defesa dos direitos animais. Com isso, objetiva-se evidenciar que o Decreto 24.645/1934, longe de ser considerado mera medida de política populista ou gesto simbólico, de fato foi utilizado para proteger os animais não-humanos, seja por meio da tutela jurisdicional, seja por meio de medidas administrativas ou de auxílio às atividades das entidades de proteção animal.

A vanguarda protetiva foi tão impactante, que chegou a ser considerada superior ao arcabouço jurídico disponível para a defesa dos próprios seres humanos, registrando-se, por isso, o uso do Decreto 24.645/1934 para a tutela jurisdicional de direitos e interesses humanos.

Considerando-se que o Decreto 24.645/1934 ainda participa do ordenamento jurídico nacional - tanto que continua a ser usado como fundamento jurisprudencial, inclusive para importantes e recentes julgados dos Tribunais Superiores brasileiros - deixa-se para o capítulo final o estudo sobre a vigência do Decreto e a ineficácia da revogação promovida pelo Decreto 11, de 1991.

\section{A origem histórica da "Lei Áurea" dos animais}

\subsection{A UIPA e a apresentação da proposta de lei}

O Decreto 24.645/1934 foi fruto de uma iniciativa da União Internacional Protetora dos Animais - UIPA, fundada em 1895, que se apresenta como a organização nãogovernamental (ONG) mais antiga do Brasil e responsável pelos primórdios, no século XIX, do movimento de proteção animal no país. ${ }^{10}$

Atuante até os dias de hoje, a UIPA se destacou por constantes tentativas de diálogo com o Poder Público, em todas as esferas de governo, propondo a criação de leis e regulamentos em favor dos animais e exigindo, inclusive pela atuação policial, a aplicação das normas protetivas existentes. ${ }^{11}$ 
Foi assim que a UIPA publicou, na edição de 04 de maio de 1934, do jornal O Estado de S. Paulo ${ }^{12}$, memorial dirigido diretamente ao "Sr. Getúlio Vargas", então chefe do Governo Provisório, ${ }^{13}$ alertando sobre a necessidade de criação de uma lei de proteção aos animais abrangendo todo o território nacional, tendo em vista que, mesmo diante da existência de leis de proteção esparsas, principalmente municipais, estas, por sua atuação limitada, não atingiam todos os animais existentes no país. "Quase todas as nações do globo possuem leis a respeito, faltando, no concerto dos países cultos, apenas que o Brasil legisle nesse sentido", relata a publicação da UIPA (figura 1).

O memorial também destaca que, em outras oportunidades - em 1912, 1914, 1922 e 1929 - foram apresentados ao Congresso Nacional projetos de leis de proteção aos animais, contudo, não foram aprovados, apesar de pareceres favoráveis de diversas comissões do Parlamento. ${ }^{14} \mathrm{O}$ relato é precioso, pois mostra que a luta pela causa animal no país é fruto de um processo contínuo de atuação organizado em várias frentes, incluindo pressão junto aos legisladores. ${ }^{15}$

A publicação apresenta importantes indícios acerca das fontes materiais da proposta de lei apresentada. Ao alertar o Presidente Getúlio Vargas sobre a necessidade de criação de lei específica, a publicação da UIPA aponta diversos documentos e legislações estrangeiras orientadas à proteção animal: touradas;

1) a Bula Papal, editada por Pio V, em 1 o de novembro de 1507, que condenava as

2) a Lei de Proteção aos Animais inglesa de 1807, em conjunto com o Protection Birds Act de 1933 (Chapter 52);

3) a Lei francesa de 2 de julho de 1850, de autoria do General Delmas de Grammont (Lei Grammont);

4) a Lei Federal argentina $n$. o 2.786, de 1/12/1891;

5) a Lei suíça, de 19 novembro 1891, regulamentando o transporte de animais em linhas férreas e navios;

6) a Lei norte-americana n.․ 463, "de proteção geral aos seres inferiores"; e

7) o art. 491 do Código Penal italiano de 1889.

O texto deixa evidente a admiração quanto à maneira pela qual a proteção animal encontrava abrigo na sociedade inglesa. ${ }^{16}$ Indica a Rainha Vitória como "grande zoophila" e presta homenagens ao Rei Jorge $V$, por ter declarado, enquanto príncipe, que suprimiria os freios dos cavalos, o que foi feito posteriormente. Além disso, a publicação transcreve a inscrição de um monumento inglês, inaugurado em homenagem aos cavalos sacrificados nas guerras anglo-boer ${ }^{17}$, que diz: "A grandeza de uma nação consiste não só na densidade do seu povo ou na extensão de seu território, mas também na extensão de sua Justiça e de sua compaixão" ${ }^{18}$

Após essas considerações preliminares, a UIPA, na mesma publicação, "pede vênia para submeter à apreciação de v. exa. o projeto de lei incluso, rogando a v. exa. se digne a transformá-lo em lei", e assim transcreve integralmente a proposta de lei, atribuída à relatoria de Affonso Vidal, ${ }^{19}$ então vice-presidente da instituição. ${ }^{20}$

$\mathrm{Na}$ ata da 136a Sessão do Conselho Diretor da UIPA ficou registrado que, de fato, foi Affonso Vidal o redator da proposta e que o texto já havia sido apresentado anteriormente como projeto de lei municipal. 


\section{PROTECÇÃO AOS ANIMAES Um memorial da Uniảo Internacional Protectora dos \\ Animaes ao chefe do governo provisorio}
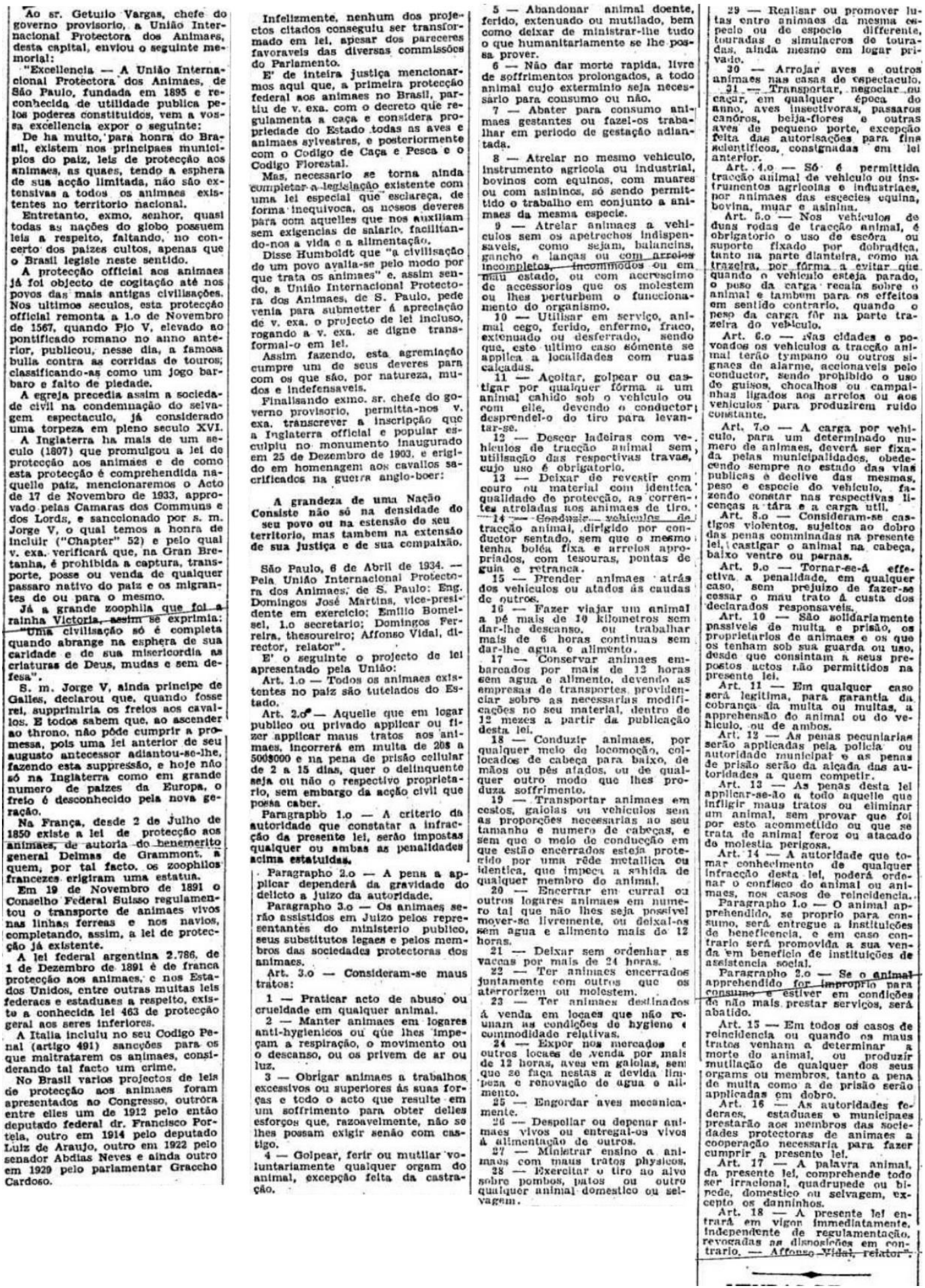

Figura 1: Recorte editado do memorial publicado pela UIPA, na edição de 04 de maio de 1934, do jornal O Estado de S. Paulo. 


\subsection{A edição do Decreto 24.645/1934}

De forma impressionante, pouco menos de dois meses após a publicação da proposta da UIPA no O Estado de S. Paulo, o seu texto foi integralmente adotado por Getúlio Vargas e pelo Ministro da Agricultura, Juarez Távora, ${ }^{21}$ sem qualquer ressalva ou alteração nos dispositivos propostos.

Publicado, ${ }^{22}$ entra em vigor o Decreto 24.645 , em 10 de julho de $1934,{ }^{23}$ com a epígrafe de estabelecer medidas de proteção aos animais. ${ }^{24}$

Durante a pesquisa histórica, foram procedidas buscas nas bases de dados do Arquivo Nacional (SIAN), no Acervo da Fundação Getúlio Vargas (CPDOC) e na Hemeroteca da Biblioteca Nacional, na tentativa de encontrar documentos com informações relativas ao período compreendido entre a publicação da proposta de lei da UIPA no O Estado de S. Paulo e sua edição por Getúlio Vargas. No mesmo sentido, foram realizados contatos com o Senado Federal, a Presidência da República, a Casa Civil e o Ministério de Agricultura, através do Sistema de Informação ao Cidadão (CIC). Em nenhum dos casos foi encontrado qualquer documento ou informação que indicasse a forma como a matéria foi tratada pelo governo Getúlio Vargas até a aprovação do Decreto 24.645/1934.

De qualquer maneira, a edição da lei foi comemorada pela UIPA como uma grande vitória. A instituição publicou, no jornal Correio Paulistano, de 13 de julho de 1934, a seguinte manifestação:

(A UIPA) acaba de receber uma comunicação diretamente do Palácio do Cattete, [...] informando haver o chefe do governo provisório assinado, ontem, o decreto da lei que orientará, em toda a República, a proteção aos animais, e de cujo anteprojeto é autor o Sr. Affonso Vidal, um dos esforçados diretores, da sociedade protetora, segundo notícias veiculadas pela imprensa de S. Paulo em abril último. ${ }^{25}$

A aprovação do Decreto representou, conforme aponta Antônio Herman Benjamin, uma incursão não-antropocêntrica, ainda na década de 30, muito antes do surgimento do ambientalismo. ${ }^{26}$

Como explicar a edição de uma lei tão inovadora e tão à frente de seu próprio tempo?

Com a ascensão de Getúlio Vargas ao poder, após a Revolução de 1930, verificou-se, num quadro geral de mudanças e de desejo de modernizar o país, uma onda legisladora que abrangia os mais diversos assuntos. Foram editados muitos Decretos, com força de lei. Em janeiro de 1934, Vargas havia baixado o Código de Caça e Pesca, o qual, dentre outros assuntos, proibia métodos cruéis de captura. ${ }^{27}$ Os associados da UIPA julgaram que seria um bom momento para apresentar sua proposta mais geral de proteção animal, pois Vargas vinha mantendo a tendência de atender as demandas de diversos grupos sociais, com o intuito de angariar apoio político de membros destacados e influentes da sociedade. ${ }^{28}$

Além disso, mesmo que o texto do Decreto 24.645/1934 tenha sido assinado ainda sobre a égide do Governo Provisório excepcional, não se pode negar que sua aprovação está inserida no contexto do debate político que envolveu a promulgação da Constituição da República dos Estados Unidos do Brasil de 1934, em cujo bojo ficou consignado um papel diferenciado para o Estado em relação ao meio ambiente, embora não houvesse uma proteção e uma atribuição de competências claras em relação à matéria. ${ }^{29}$

Naquele momento histórico, a defesa do meio ambiente possuía finalidade diferente da que hoje é reconhecida. Neste sentido, afirma Fernanda Medeiros: 
(...)os elementos da natureza tinham por escopo a racionalização econômica das atividades de exploração dos recursos naturais, de forma alguma pretendiam promover a defesa ambiental, tal como hoje a entendemos. De qualquer sorte, apesar de não possuírem uma visão holística do ambiente e nem uma conscientização de preservacionismo, por intermédio de um desenvolvimento técnicoindustrial sustentável, essas Cartas tiveram o mérito de ampliar, de forma significativa, as regulamentações referentes ao subsolo, à mineração, à flora, à fauna, às águas, dentre outros itens de igual relevância. ${ }^{30}$

Sob o enfoque ambiental, e no contexto pós-Revolução de 30, a Constituição de 1934 pode ser caracterizada como sem unidade ideológica, com pressupostos herdados da Carta Mexicana de 1917 e da Lei Fundamental alemã de Weimar (1919), fontes históricas do moderno constitucionalismo. Assim, mesmo tendo sido editado seis dias antes do texto constitucional de 1934, é nessa conjuntura que surge o primeiro estatuto geral de proteção animal do Brasil. $^{31}$

Conforme já apontado, a aprovação do Decreto 24.645/1934 foi alardeada pela UIPA como uma grande vitória, também porque, no plano político, ficou estabelecida a centralidade das sociedades protetoras dos animais, ainda que ao lado do Ministério Público.

$\mathrm{O}$ artigo 2 으, $\S 3$ 으 do Decreto erigiu as sociedades protetoras dos animais ao mesmo patamar do Ministério Público, como representantes/assistentes dos animais em juízo. ${ }^{32} \mathrm{~A}$ consagração das entidades de proteção animal também vem estampada nas disposições do art. 16, ao prever que "as autoridades federais, estaduais e municipais prestarão aos membros das sociedades protetoras de animais a cooperação necessária para fazer cumprir a presente lei".

A UIPA, e as demais entidades de proteção animal existentes à época, ganharam força política com a edição do Decreto 24.645/1934.

\subsection{A difusão do Decreto como "Lei Áurea" dos animais}

O Decreto 24.645/1934 é um estatuto jurídico geral dos animais, pois proclama, em seu artigo de abertura, que todos os animais existentes no país passam a ser tutelados pelo Estado. Não passam a ser propriedade do Estado. ${ }^{33}$ Passam a ser responsabilidade estatal, objetos de deveres protetivos, tal como, hoje, proclama o art. 225, §1ํ, VII, da Constituição Federal.

Para a consecução desses deveres, foram tipificadas práticas consideradas como maus-tratos (art. $3 \circ$ ) , punindo-se, criminalmente, quem os praticasse, com penas de multa e de prisão de 2 a 15 dias (art. 2ㅇ). Nasce, pela primeira vez, o crime contra a dignidade animal, atualmente previsto no art. 32 da Lei 9.605/1998. ${ }^{34}$

Para o Decreto, no entanto, "A palavra animal, da presente lei, compreende todo ser irracional, quadrúpede ou bípede, doméstico ou selvagem, exceto os daninhos", excluindo da tutela da lei aqueles animais considerados prejudiciais aos seres humanos, bem como os animais aquáticos (objetos de pesca).

Mesmo com essa ressalva, não se pode negar a "evidente e (surpreendente!)" orientação biocêntrica do Decreto 24.645/1934, "promulgado na mesma década do nosso primeiro Código Florestal, extremamente antropocêntrico". ${ }^{35}$ 
De todo modo, foi notável a influência exercida pela União Internacional Protetora dos Animais, ao propor e conseguir transformar em lei federal o projeto de sua autoria, estabelecendo no ordenamento jurídico brasileiro, pela primeira vez, uma série de dispositivos destinados exclusivamente aos animais não-humanos.

A partir de sua edição, a UIPA começou a trabalhar na distribuição e efetivação do Decreto. Não se contentou, apenas, com a aprovação da lei. O objetivo da organização era o de influenciar o maior número de pessoas em relação à necessidade de proteção dos animais. ${ }^{36}$

Em publicação no Correio Paulistano, de 13 de maio de 1938, consta que:

[...] só o Sr. Vidal distribuiu no segundo semestre do ano de 1934, a expensas suas, para mais de 20.000 exemplares da "Lei Áurea dos Animais", enviando-os, indistintamente a todas as autoridades estaduais e municipais, centros religiosos e educativos, a juízes e notadamente aos jornais de todo o Brasil, grande partes dos quais transcreveram em suas colunas a lei, pela U.I.P.A. A denominada LeiVidal $[\ldots]^{37}$

A alusão à Lei Áurea aparece, pela primeira vez, em publicação datada de 20 de outubro de 1934, do Diário da Tarde (Curitiba) ${ }^{38}$, na notícia em que a UIPA informa que o Chefe do Governo Provisório decretou lei de proteção aos "seres inferiores" e indica que a publicação da Lei Áurea dos Animais "prestará um serviço à coletividade, promovendo a cultura e desenvolvendo os bons sentimentos em aqueles que, por ignorância ou maldade até aqui tem negado direitos aos entes que por natureza são mudos e indefensáveis".

Oportuna a análise de Natascha Stefania Carvalho de Ostos acerca do termo Lei Áurea dos animais:

A comparação com a lei áurea, que aboliu a escravidão no Brasil, remetia à condição de submissão dos animais do país, pressupondo a vigência de situações de crueldade, exploração, abuso e dominação injusta; mais do que isso, insinuava que circunstâncias de vida tidas como arbitrárias e iníquas para os seres humanos tampouco poderiam prevalecer para os animais. Em que pese o impacto da comparação, a lei não deixou de circunscrever, na própria definição de animal, quais bichos estariam sob o seu amparo, procurando mais regular a forma de usar o trabalho dos animais do que abolir a sua exploração. ${ }^{39}$

Pontuadas as críticas aos critérios de utilidade progressiva, aparentes no texto do Decreto, não se deve esquecer que a sua edição ocorreu nos anos 30, conforme asseverado por Antônio Herman Benjamin, "muito antes da era do ambientalismo" e, desta forma, o Decreto surge como verdadeiro divisor de águas que marca, nas palavras de Laerte Fernando Levai, "o início de uma nova consciência. Tempo de Despertar...". ${ }^{40}$

Neste sentido, a referência à Lei Áurea parece ir ao encontro do significado que pode ser extraído, ainda hoje, do Decreto 24.645/1934: assim como a abolição da escravidão humana no Brasil se deu por etapas bem definidas (proibição do tráfico negreiro em 1831, Lei do ventre-livre de 1871, Lei dos sexagenários de 1885, até a abolição total em 1888), também o movimento abolicionista animal ${ }^{41}$ encontra, na aprovação do Decreto de 1934, seu marco legislativo inaugural. 
Isso se dá não apenas por definir condutas consideradas como cruéis (e, portanto, criminosas), mas principalmente por reconhecer a capacidade de ser parte dos animais (art. 2o, $\S 30),{ }^{42}$ do que se podem extrair consideráveis argumentos em prol da elevação do status jurídico dos animais para sujeitos de direitos, e não mais de bens, coisas ou objetos. ${ }^{43}$

\section{Possíveis fontes materiais da proposta de lei da UIPA - a importância do Protection of Animals Act inglês de 1911}

$\mathrm{Na}$ pesquisa histórica, também foram averiguadas as possíveis influências que inspiraram Affonso Vidal, vice-presidente da UIPA, a redigir e a propor tantos dispositivos legais inovadores.

Como já mencionado, na edição de 04 de maio de 1934, do jornal o Estado de S. Paulo, quando apresentada a proposta de lei, foram indicados vários documentos internacionais, que há tempos, de alguma forma, protegiam os animais.

Já se noticiou a evidente admiração expressada pela UIPA em relação à forma com que o ordenamento jurídico inglês vinha tratando a questão. ${ }^{44}$ Apontam que, na Grã-Bretanha, em 17 de novembro de 1933, foi sancionado pelo Rei Jorge V, o Ato de Proteção aos Pássaros (Protection of Birds Act), "proibindo a captura, transporte, posse ou venda de qualquer pássaro nativo do país e os migrantes de ou para o mesmo."

Apesar de não indicado na notícia, o primeiro dispositivo legal sistemático de proteção aos animais, no Reino Unido, recebeu aprovação real em 11 de agosto de 1911: o Protection of Animals $\mathrm{Act}^{45}$ consolidou, alterou e estendeu, a leis anteriores, algum tipo de proteção aos animais.

Diante da similaridade de alguns dispositivos, é provável que esse ato normativo inglês tenha influenciado mais diretamente a redação da proposta de lei, pois, comparando os dois instrumentos legais, é possível identificar muitas semelhanças nos atos tipificados como maus-tratos no Decreto 24.645/1934, com aqueles assim considerados no Protection of Animals Act.

Dentre as condutas consideradas como crueldade com os animais pelo Animals Act tem-se: bater com crueldade, chutar, maltratar, submeter a percursos exaustivos (quando o animal for usado para montaria ou carga), torturar, enfurecer, aterrorizar, causar sofrimento desnecessário; transportar animais de forma ou em posição que causem sofrimento desnecessário; causar, procurar ou auxiliar, provocar ou dar assistência a lutas ou combates (fighting or baiting) de qualquer animal; administrar veneno ou qualquer produto que cause sofrimento ao animal sem nenhuma causa razoável; submeter a qualquer tipo de intervenção cirúrgica realizada sem cuidado e humanidade. ${ }^{46}$

Em alguns incisos do artigo 3o do Decreto 24.645/1934 pode-se observar redação semelhante à do Animals Act inglês.

Confira-se:

Art. 3 ㅇ Consideram-se maus tratos:

I- praticar ato de abuso ou crueldade em qualquer animal;

$(\ldots)$

III - obrigar animais a trabalhos excessivos ou superiores às suas forças e a todo ato que resulte em sofrimento para deles obter esforços que, razoavelmente, não se lhes possam exigir senão com castigo; 
IV - golpear, ferir ou mutilar, voluntariamente, qualquer órgão ou tecido de economia, exceto a castração, só para animais domésticos, ou operações outras praticadas em beneficio exclusivo do animal e as exigidas para defesa do homem, ou no interesse da ciência;

(...)

XXII- ter animais encerrados juntamente com outros que os aterrorizem ou molestem;

$(\ldots)$

XXIX- realizar ou promover lutas entre animais da mesma espécie ou de espécie diferente, touradas e simulacros de touradas, ainda mesmo em lugar privado;

$(\ldots)$

O Animals Act de 1911 também determinava, sob pena de multa, nos casos de aprisionamento e confinamento de animais por períodos superiores a seis horas, a obrigação de fornecer quantidade suficiente de comida e água. ${ }^{47}$ Tem-se, no Decreto 24.645/1934, dispositivos com vedações semelhantes:

Art. 3‥ Consideram-se maus tratos:

$(\ldots)$

XX -encerrar em curral ou outros lugares animais em úmero tal que não Ihes seja possível moverem-se livremente, ou deixá-los sem água e alimento mais de 12 horas;

$(\ldots)$

XXIV - expor, nos mercados e outros locais de venda, por mais de 12 horas, aves em gaiolas; sem que se faça nestas a devida limpeza e renovação de água e alimento;

$(\ldots)$

Nos termos do Animals Act, qualquer pessoa que incidisse nestas condutas proibidas seria considerada culpada por crueldade contra animais e sujeita à pena de multa, além de prisão, alternativamente ou em conjunto, por até seis meses, com ou sem trabalhos forçados: nítidas semelhanças com o sistema de penas do art. 2o caput do Decreto 24.645/1934.

Existem, ainda, no Decreto, outros dispositivos que guardam semelhanças com os itens do Animals Act inglês de 1911. Contudo, o objeto aqui não é fazer uma profunda análise comparativa, mas somente demonstrar, seguindo os indícios trazidos pelas notícias pesquisadas, a possível influência britânica no texto do Decreto.

Outras legislações também foram citadas na parte introdutória da publicação original da UIPA. Dentre elas, a Lei Federal argentina n. 2.786, de 25 de julho de 1891, a Lei francesa de 2 de julho de 1850, sobre maus-tratos a animais domésticos (Lei Grammont), e o art. 491 do Código Penal italiano de 1889.

Vale a pena fazer uma breve incursão a esses dispositivos do Direito Comparado.

Na Lei Federal argentina n.o 2.786, de 25 de julho de 1891, ${ }^{48}$ o art. 20 contém orientação expressa para que as autoridades cooperem com as entidades protetoras dos animais, no mesmo sentido do que constou no art. 16 do Decreto 24.645/1934: 
ARTícULO 2.- En la capital de la República y Territorios Nacionales, las autoridades policiales prestarán a la Sociedad Argentina Protectora de los Animales, la cooperación necesaria para hacer cumplir las Leyes, reglamentos y ordenanzas dictadas o que se dicten en protección de los animales, siendo de la competencia de las mismas, el juicio y aplicación de las penas en la forma en que lo hacen para las contravenciones policiales. ${ }^{49}$

A Lei francesa, de 2 de julho de 1850, sobre maus-tratos a animais domésticos, conhecida como Lei Grammont, tratava do assunto da seguinte forma:

Serão punidos com uma multa de cinco a quinze francos, e podem ser punidos com pena de prisão de um a cinco dias, aqueles que exercerem publicamente e abusivamente tratamentos ruins a animais domésticos. A pena de prisão será sempre aplicada em caso de reincidência.

O artigo 483 do código penal será sempre aplicável. ${ }^{50}$

Este dispositivo da lei francesa, em conjunto com a parte final do item 1 do Protection of Animals Act inglês, pode ter influenciado o sistema de determinação de penas trazido pelo artigo 2 o do Decreto $24.645 / 1934 .^{51}$ Da mesma forma, pode ter influenciado a previsão de agravamento de pena, seja nos casos de multa ou de prisão, que deveria ser dobrada nos casos de reincidência ou morte do animal (como o faz o art. 15 do Decreto). ${ }^{52}$

Finalmente, nos termos do art. 491 do Código Penal Italiano de $1889,{ }^{53}$ qualquer pessoa que se envolvesse em práticas de crueldade com animais ou, sem necessidade, os tratasse mal ou os forçasse excessivamente, seria punida com multa. À mesma pena estaria sujeito aquele que, mesmo apenas para fins científicos ou educacionais, mas fora dos locais de ensino, sujeitasse os animais a experimentos que provocassem aversão. ${ }^{54}$

Dessa breve colação dos dispositivos legais estrangeiros indicados pela UIPA e que, muito provavelmente, constituíram as fontes materiais da redação da proposta de lei, destacase, nitidamente, o Protection of Animals Act inglês de 1911.

Todavia, em nenhum dos textos legais estrangeiros foi encontrado qualquer trecho que, ao menos aparentemente, tenha influenciado, direta ou indiretamente, a fantástica redação do art. 2ㅇ, § 3ㅇdo Decreto 24.645/1934, o qual outorga capacidade de ser parte aos animais não-humanos, mediante representação pelo Ministério Público, pelos seus substitutos legais ou pelas sociedades protetoras dos animais.

\section{O Decreto na prática}

\subsection{O Decreto na proteção animal}

Depois de tratar das origens históricas e das possíveis fontes materiais do Decreto 24.645/1934, cabe agora verificar a forma como foi utilizado ao longo do tempo.

Para tanto, além das notícias do período 1934-1939, foram estudadas outras publicações relevantes ao tema, de períodos posteriores. 
Como visto, após a aprovação do texto publicado pela UIPA, a instituição passou a trabalhar na distribuição e efetivação do Decreto, com o objetivo de influenciar o maior número de pessoas em relação à necessidade de proteção dos animais. Somente o redator, Affonso Vidal, distribuiu, no segundo semestre de 1934, "mais de 20.000 exemplares da 'Lei Áurea dos Animais', enviando-os a todas as autoridades estaduais e municipais, centros religiosos e educativos, a juízes e notadamente aos jornais de todo o Brasil [...] denominada LeiVidal". 55

Mas a UIPA não foi a única a dar publicidade ao Decreto.

Foram encontradas referências de outras instituições, como a Sociedade Paulista de Proteção aos Animais $^{56}$ e a Associação de Proteção do Rio de Janeiro, ${ }^{57}$ que realizaram distribuição e outras atividades para difundir o conteúdo do Decreto.

Outras notícias dão conta de ações das autoridades para fazer valer a Lei de proteção dos animais, muitas vezes em resposta a requisições de entidades de protetores. Tem-se, por exemplo, na edição de 13 de agosto de 1934, do jornal catarinense O Estado, nota sobre a ação do Delegado de Polícia da região, reunido carroceiros para ler e entregar-Ihes cópias do Decreto e conferindo a eles 30 dias para que melhorassem os arreamentos e medicassem os cavalos usados para tração. ${ }^{58}$

Mais um exemplo é visto na edição de 04 de fevereiro de 1938, do Diário de Notícias (Rio de Janeiro), trazendo o registro: "A diretoria do Abrigo de Proteção aos Animais (APA), em ofício dirigido ao exmo. Sr. Cap. Felinto Muller, chefe de Polícia do Distrito Federal, solicitou a execução do Decreto Federal n. 24.645 e teve comunicação do despacho favorável...". ${ }^{59}$ Nesta mesma notícia relata-se que o Chefe de Polícia expediu ordens para que todas as autoridades policiais prestarem apoio às pessoas portadoras de carteiras que comprovem a filiação às entidades de proteção aos animais.

O Decreto também foi invocado para impedir a realização de touradas. Em publicação datada de 1938, lê-se:

O Chefe de Governo indeferiu o requerimento de um empresário, interessado em fazer realizar, em uma de nossas praças de esporte, algumas touradas. (...) o decreto n. 24.645 de 10 de julho de 1934, repelira esse triste espetáculo que não se compadece com nossos foros de povo civilizado[... $]^{60}$

Opondo-se à proibição, posteriormente, já em 1950, foi apresentado projeto de lei para retirar a proibição das touradas e corridas de touros, desde que fossem realizadas "sem o uso de instrumentos capazes de produzir tortura nos animais ou causar-lhes a morte". ${ }^{61} \mathrm{~A}$ proposta foi logo rejeitada pela Câmara dos Deputados, de forma que a proibição às touradas permanece vigente. $^{62}$

As notícias acima descritas demonstram como o Decreto oferecia, mesmo antes da promulgação da Constituição de 1988, fundamentos suficientes, especialmente pela interpretação dos incisos I, IV e XXIX do artigo 3으, para proibir práticas de crueldade contra animais as quais, até recentemente, permaneciam toleradas, como a farra do boi ${ }^{63}$ e a vaquejada. ${ }^{64}$ Por isso mesmo, o Decreto foi utilizado para criticar as práticas de "boi-na-vara"65 e, também, muitos anos depois de sua publicação, as da farra do boi. ${ }^{66}$

Talvez mais incisiva foi a presença, no noticiário na época, dos casos envolvendo a criminalização dos maus-tratos a animais, a partir dos tipos penais estabelecidos pela conjugação do art. 2o com o art. 3o do Decreto 24.645/1934. 
A primeira notícia encontrada data de 10 de novembro de 1934: “O Promotor Público da Comarca de Niterói, Dr. Melchiades Picanço, ofereceu ontem denúncia contra Antonio de Oliveira, por se achar o mesmo incurso no art. 13 combinado com o artigo 20 do decreto n. 24.645 de 10 de julho de 1934". O denunciado estava sendo acusado por ter desferido tiros contra a cabra pertencente a seu vizinho, "animal de grande estimação e que dava leite para alimentar os filhos do dono". Da nota se extrai, no contexto, o mandamento do artigo 2으, §3ㅇ, do Decreto: "A denúncia em questão é a primeira oferecida em Niterói com fundamento no decreto que declarou tutelados do estado todos os animais, cabendo ao Ministério Público assisti-los em juízo". ${ }^{67}$

Em outro caso, "Biagio Rivelino foi processado por haver desfechado um tiro de espingarda na cadela de propriedade de Kurt Rigert [...]. A requerimento do sr. 10 Promotor Público, Dr. J.A. Cesar Salgado, o inquérito voltou [...] à delegacia de Segurança Pessoal para ser feita autópsia". Ocorre que por "negligência de funcionário falho", a autopsia requisitada não foi realizada a tempo, acabando por correr a prescrição da pretensão punitiva. ${ }^{68}$ Um outro jornal diário que abordou a mesma situação, de forma diferenciada, noticiou o julgamento ocorrido em Curitiba, com base no Decreto 24.645/1934, no qual "um cidadão foi punido por ter este maltratado um animal doméstico." 69 Publicação mais próxima da data do fato revela que o "dono da cadelinha" procurou o Procurador-Geral "com farta prova testemunhal" e "laudo de autópsia". Diante disso, o Procurador pediu a abertura do inquérito, por ser o respectivo crime de ação pública, nos termos do Decreto 24.645/1934, "estando, portanto, Biagio nele incurso: artigo 2 parágrafo 3 da lei em apreço". De fato, a possibilidade de processar e condenar com base no Decreto trazia certa desconfiança e surpresa, sendo por vezes ironizada. A notícia relata erroneamente que o autor do crime seria processado por homicídio e, de forma jocosa, termina com a pergunta "o crime é de homicídio ou de 'canicídio'?"70

Num outro exemplo, dois homens, pai e filho, foram "processados e afinal condenados a cumprir a pena de 10 dias de prisão e a pagar a multa de 200\$000..", por terem, em via pública, abatido dois cães, um a facadas e outro a cacetadas. Os réus apelaram da sentença. Os juízes do Tribunal de Apelações, alertando sobre a característica hoje chamada de senciência, inerente aos animais, argumentaram que "só aplausos merece o novo decreto, pois é sabido que os animais são também dotados de sensibilidade e de instintos aprimorados", mantendo a sentença. Nesse mesmo acórdão surge também a comparação entre o Código de Menores abandonados e a Decreto dos Animais:

A proteção aos animais, de fato, ultrapassa a garantida aos menores abandonados [...] os animais não podem ser conservados em lugares anti-higiênicos [...]. Entretanto, com relação aos menores, o mesmo não acontece, pois, como é público e notório, vivem eles nos porões anti-higiênicos e infetos, em franca promiscuidade, constituinte, muitas vezes, um verdadeiro atentado à moral. ${ }^{71}$

Tal sorte de relatos demonstra, uma vez mais, a natureza precursora e vanguardista do Decreto, por trazer normas de defesa dos animais, mesmo em período no qual a defesa dos próprios seres humanos era pouco consistente. Houve impactos na realidade e no dia a dia das pessoas e das autoridades públicas. A questão assumiu uma notoriedade antes não sentida. 
Vicente de Paula Ataide Junior e Thiago Brizola Paula Mendes

\subsection{O Decreto na proteção de direitos humanos}

Por vezes, o Decreto 24.645/1934, por seu avanço radical, foi utilizado na defesa dos direitos humanos. ${ }^{72}$

No mesmo ano de sua publicação, o Decreto serviu para criticar as condições insalubres e degradantes às quais os operários eram submetidos. Em jornal da época foi publicado: "Sei de animais que vivem em lugares anti-higiênicos, quase privados de luz", "são magros e tristes", "andam desferrados", "creio mesmo que os animais citados não gozam de nenhuma das garantias do excelente decreto n. 24.645"; são algumas das afirmações trazidas pelo autor do artigo, que, ao final, revela que "devido a certas semelhanças, algumas pessoas pensam que esses animais são homens. É engano. Eles de fato, têm alguma parecença com os homens: mas não são homens, são operários." ${ }^{73}$

Um defensor do Decreto relatou ter encontrado na imprensa de São Paulo, Rio de Janeiro e Curitiba, afirmações sustentando que, diante dos incalculáveis sofrimentos humanos, "dever-se-ia tratar primeiro de banir estes dando aos homens o bem-estar e a felicidade que todos procuram". ${ }^{74}$

Mas, o caso mais emblemático envolvendo a aplicação do Decreto 24.645 para seres humanos diz respeito à situação de maus-tratos a presos políticos durante o primeiro governo Vargas.

Em 26 de dezembro de 1935, Harry Berger (codinome de Arthur Ernest Ewert) foi preso por sua participação na "Intentona Comunista" (movimento encabeçado por Luiz Carlos Prestes, que pretendia depor Getúlio Vargas, em 1935). ${ }^{75}$ Ciente das terríveis torturas que Berger vinha sofrendo, o advogado Sobral Pinto alegou ao Tribunal de Segurança Nacional que o preso estava sofrendo formas de crueldade inadmitidas até mesmo "para com os irracionais", conforme trecho da petição a seguir:

Tal é, Sr. Juiz, a prisão que destinaram para Harry Berger. Tal é, eminente Magistrado, o tratamento que lhe vem sendo dispensado.

Semelhante desumanidade precisa de cessar, e de cessar imediatamente, sob pena de deslustre para o prestígio deste Tribunal de Segurança, que, para bem cumprir a sua árdua tarefa necessita de pautar a sua ação pelas normas inflexíveis da serenidade e da justiça.

Tanto mais obrigatoriamente inadiável se torna a intervenção urgentíssima de V. Exa., Sr. Juiz, quanto somos um povo que não tolera a crueldade, nem mesmo para com os irracionais, como o demonstra o decreto $\mathrm{n}$ - 24.645, de 10 de julho de 1934, cujo artigo 10 dispõe: "Todos os animais existentes no país são tutelados do Estado. ${ }^{76}$

Para demonstrar a aplicação do Decreto 24.645/1934, Sobral Pinto invocou notícia vinculada pelo jornal carioca $A$ Noite, contendo relato sobre a condenação a 17 dias de prisão e multa, de homem que espancou até a morte seu cavalo, pois, nas palavras do autor do crime, "o seu amigo irracional desobedeceu-o". ${ }^{77}$

Baseado nesse caso, ocorrido em Curitiba, Sobral Pinto alegou:

Ora, num país que se rege por uma tal legislação, que os Magistrados timbram em aplicar, para, deste modo, resguardarem os próprios animais irracionais dos maus tratos até de seus donos, não é possível que Harry Berger permaneça, como até agora, meses e meses a fio, com a anuência do Tribunal de Segurança Nacional, dentro de um 
socavão de escada, privado de ar, de luz e de espaço, envolto, além do mais, em andrajos, que, pela sua imundície, os próprios mendigos recusariam a vestir. ${ }^{78}$

Conforme explica Daniel Monteiro Neves, a menção ao ocorrido na capital paranaense teve o objetivo de evidenciar a incompatibilidade entre atitudes oriundas de um mesmo Estado perante os animais em sentido amplo. ${ }^{79}$

Em outro caso, bem mais recente, datado de julho de 1988, ação ajuizada pela Ordem dos Advogados do Brasil, Seccional do Distrito Federal, visava a impedir despejos e derrubada de barracos em comunidades carentes, prática que vinha sendo adotada pelo governador distrital. Desta vez, o pedido foi deferido por liminar dada "com base na lei no 24.645 de 1934, que proíbe maus tratos aos animais". 80

Também no âmbito previdenciário tem-se outro caso de aplicação da lei de proteção aos animais, para seres humanos. Ocorrido no início dos anos 90, no Rio de Janeiro, um senhor idoso, para manter sua aposentadoria, alegou em juízo que os animais são tutelados pelo Estado, vedada a prática de maus-tratos contra eles. O ser humano, por sua vez, só gozaria de tutela do Estado se preenchesse uma série de requisitos. Indicou, ainda, que a suspensão da aposentadoria tornaria sua vida indigna. Desta forma, logrou êxito em conseguir, perante o Tribunal Regional Federal da 2a Região, um salário-mínimo de aposentadoria, valendo-se do fundamento legal existente no Decreto 24.645/1934. ${ }^{81}$

Assim, diante dos exemplos trazidos, é bastante oportuna a afirmação de Arthur Regis ao sustentar que "mesmo sob a égide do antropocentrismo, os próprios seres humanos, para sua proteção, utilizaram-se de legislações de proteção aos animais visando defender seus interesses particulares mais basilares" ${ }^{82}$

\section{Vigência do Decreto 24.645/1934 e ineficácia da revogação via Decreto Presidencial 11/1991}

Duas razões práticas levam à necessidade de afirmar a vigência do Decreto 24.645, ainda que proveniente de um período de exceção, no qual as discussões sobre os modernos Direitos Ambiental e Animal ainda não existiam: a categorização específica dos maus-tratos a animais e o reconhecimento da capacidade de ser parte dos animais em processos judiciais.

Em 1991, o Presidente da República Fernando Collor de Mello revogou, via Decreto 11 , de 18 de janeiro de 1991, ${ }^{83}$ diversos atos governamentais editados por governos anteriores, entre eles o Decreto 24.645/1934. Tratou-se de uma iniciativa de limpeza normativoregulamentar, ainda que efetivada sem o cuidado necessário. ${ }^{84}$

Ao contrário do que talvez supôs o ex-Presidente Collor, o Decreto 24.645/1934, dentre outros, não era um simples decreto presidencial, de natureza executiva ou regulamentar.

Quando publicado, o Decreto 24.645 possuía força de Lei ordinária, com autonomia própria, sem visar a simplesmente regulamentar uma lei preexistente, de maneira que só poderia ser revogado por outra Lei ordinária, aprovada pelo Congresso Nacional, em tempos democráticos. Isso nunca aconteceu.

A força legal do Decreto 24.645/1934 evidencia-se a partir da comezinha diferenciação da natureza jurídica entre Decreto (presidencial) e Lei. 
Enquanto a Lei é ato normativo primário, que institui direitos e deveres, cuja edição é função típica do Poder Legislativo, ${ }^{85}$ o Decreto figura como espécie de ato regulamentar (regulamento executivo), de competência do Chefe do Poder Executivo, expedido com a finalidade de produzir as disposições operacionais uniformizadoras necessárias à execução de lei preexistente, cuja aplicação demande atuação da administração. A Lei, portanto, possui posição hierárquica superior em relação ao Decreto (executivo). A Lei inova em caráter inicial a ordem jurídica, tarefa não destinada ao Decreto. Assim, a Lei é fonte primária do direito, ao passo que o Decreto é fonte secundária. ${ }^{86}$

O Decreto 24.645/1934 trouxe ao ordenamento jurídico brasileiro normas de Direito Penal (arts. 2으, $\S \S 10$ e 2으, 8ㅇ e 15), normas de Direito Processual (arts. 2ㅇ, $\S 3 ㅇ$ e 12) e a grande maioria das suas normas são de Direito Administrativo (como as que regularam a utilização de animais como tração de veículos), hoje mais bem posicionadas como normas de Direito Ambiental e de Direito Animal (os demais artigos do Decreto). Nenhum artigo visou a simplesmente executar as disposições primárias contidas em lei preexistente. O Decreto 24.645/1934, como um todo, é o primeiro estatuto jurídico geral do Direito Animal brasileiro, com normas jurídicas de variada natureza (penal, processual, administrativa/ambiental/animal), mas todas reservadas à Lei em sentido formal.

Veja-se o impacto, por exemplo, de se afirmar que "todos os animais existentes no País são tutelados pelo Estado" (art. 1ํ), criando deveres estatais relevantíssimos, ou que "Os animais serão assistidos em juízo pelos representantes do Ministério Público, seus substitutos legais e pelos membros das sociedades protetoras de animais" (art. 2o, §3으), outorgando capacidade de ser parte a animais não-humanos: ninguém poderá afirmar que disposições dessa natureza têm mero caráter regulamentador ou que seriam passíveis de integrar a ordem jurídica brasileira por mero decreto executivo!

Ainda que, à época, não existissem os chamados Decretos-Leis - mecanismo de outorga ao Executivo de uma parcela da função legislativa (o direto poder de legislar) ${ }^{87}$ - é evidente a semelhança. O Decreto 24.645, de 10 de julho de 1934, foi editado sob a égide do Decreto 19.398, de 11 de novembro de 1930, que estabeleceu o Governo Provisório e atribuiu ao Presidente da República revolucionário as funções do Poder Executivo e do Poder Legislativo, até a promulgação de nova Constituição. Assim, o Presidente Getúlio Vargas, ao editar Decreto estabelecendo medidas de proteção aos animais não-humanos, claramente realizou atividade normativa primária, tendo em vista a inovação trazida ao ordenamento jurídico pelos dispositivos do Decreto 24.645/1934.

Embora a denominação Decreto-Lei tenha aparecido no ordenamento brasileiro somente na Constituição outorgada de 1937 (art. 12 e 13), ${ }^{88}$ fica evidente, por se tratar de ato emanado do Poder Executivo, quando este acumula funções do legislativo, a correspondência conceitual entre o dispositivo em análise e a definição de Decreto-Lei. Mais adequado, portanto, seria chamar de Decreto-Lei 24.645/1934.

Mas essa disparidade terminológica é desinfluente na caracterização do Decreto 24.645 como autêntica Lei, dando o seu amplo caráter de inovação primária do ordenamento jurídico.

Em outras palavras, o Decreto 24.645/1934 não é um simples Decreto, mas verdadeira Lei, em todos os seus termos, e não apenas em relação às disposições penais.

Permanece, desta forma, em vigor o Decreto $24.645 / 1934^{89}$, pois, conforme defende Antônio Herman Benjamin, somente Lei aprovada pelo Congresso Nacional poderia tê-lo revogado. $^{90}$ 
Não se defende aqui, contudo, a vigência integral do Decreto, da forma com que foi originalmente editado, pois, já na década de 1940, a Lei das Contravenções Penais (Decreto-Lei 3.688/41) transformou em contravenção penal a crueldade contra animais, cominando aos infratores penas e multas, nos termos de seu artigo 64, já revogado. ${ }^{91}$ Posteriormente, sob égide da atual Constituição, que trouxe expressa a proibição a crueldade (art. 225, §1으, inciso VII), a Lei de Crimes Ambientais (Lei Federal 9.605/1998), nos termos do artigo 32, ${ }^{92}$ passou a considerar o abuso, os maus-tratos, o ferimento ou a mutilação de animais como crime, revogando, portanto, o artigo 64 da Lei de Contravenções, que regulava a mesma situação.

Em outras palavras, somente os artigos (ou parte deles) que estabeleciam crimes e suas respectivas penas foram revogados, tacitamente, pelos dispositivos penais posteriores. 0 que não existe mais é o sistema penal idealizado pelo Decreto. Foram revogados, tacitamente,

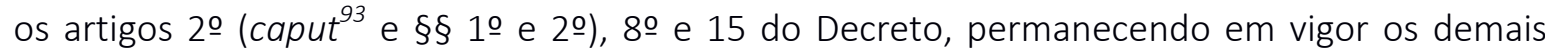
artigos, inclusive o $\S 3 \circ$, do artigo $2 \circ$, como parte do atual estatuto jurídico geral dos animais.

Mas deve se observar que o artigo 32 da Lei 9.605/1998 tipificou, mas não definiu, o que se deve entender por maus-tratos, o que continua a ser explicitado pelo Decreto 24.645/1934. ${ }^{94}$ Este Decreto não define mais o que é o crime, - tarefa do art. 32 da Lei 9.605/1998 - mas ajuda a preencher o espaço normativo indeterminado da expressão maustratos $^{95}$. Assim, conforme sustenta José Henrique Pierangeli, em parecer acerca da vigência do Decreto, "a lei nova recepciona conceitos e definições que não foram expressamente - e só por essa forma poderiam sê-lo -, revogados". ${ }^{96}$

Desta forma, "com exceção feita ao superado sistema de penas ali previsto, o Decreto 24.645/34 não foi revogado por nenhuma lei posterior, nem expressa, nem tacitamente." 97 Não há razão para negar que o Juiz criminal, ao aplicar o art. 32 da Lei 9.605/1998, na modalidade maus-tratos, evoque algum dos incisos do art. 3o do Decreto 24.645/1934, para especificar melhor a tipicidade e a antijuridicidade da conduta aferida. ${ }^{98}$

Assim, mesmo as disposições do art. 3으 do Decreto em estudo continuam em vigor, constituindo importante instrumento normativo para a atuação civil e administrativa de combate aos maus-tratos contra animais, além de auxiliar a configuração típica do crime previsto no art. 32 da Lei 9.650/1998.

O Decreto 24.645/1934, insista-se, está em vigor (com exceção, apenas, das suas disposições penais) e, prova disso, é que continua sendo utilizado na fundamentação de importantes decisões judiciais das Cortes Supremas brasileiras: no Supremo Tribunal Federal, conforme ADIn 1.856-6/RJ, na linha do voto do relator, Ministro Carlos Velloso, pela qual foi declarada a inconstitucionalidade da lei carioca que regulamentava a "briga de galos" 99 ; no Superior Tribunal de Justiça, conforme REsp 1115916/MG, ementa e voto do Ministro Humberto Martins, pelo qual foi mantido acórdão do Tribunal de Justiça de Minas Gerais, que impedia o uso de gás asfixiante no abate de cães, considerado prática cruel. ${ }^{100}$

\section{Conclusão}

Do ponto de vista histórico é interessantíssima a dinâmica que levou à edição do Decreto 24.645/1934.

Uma simples matéria de jornal chega ao conhecimento do Presidente da República, que aprova, adota e edita a proposta de lei contida no noticiário, integralmente, sem nenhuma ressalva ou alteração. 
Vicente de Paula Ataide Junior e Thiago Brizola Paula Mendes

De fato, permanece nebulosa a tramitação da proposta, se é que houve alguma, entre sua publicação jornalística, em 04 de maio de 1934, e a edição do Decreto, em 10 de julho do mesmo ano.

Ocorre que, como o Decreto foi aprovado em período de exceção, sem submissão ao Congresso Nacional, não é improvável que o então Ministro da Agricultura, Juarez Távora, tenha levado o texto sugerido diretamente ao conhecimento do Presidente Getúlio Vargas ou, então, que este mesmo tenha tomado conhecimento direto do conteúdo e assim tenha ordenado sua adoção, sem qualquer revisão ou discussão prévia.

De qualquer forma, mesmo com esse déficit democrático, o Decreto inovou a ordem jurídica e irradiou sua eficácia, tendo sido utilizado não apenas na defesa dos animais nãohumanos, mas também para proteger os interesses dos animais os quais, na maior parte das vezes, se esquecem da sua condição natural: os humanos.

Sem a pretensão de defender o Decreto 24.645/1934 como justo e perfeito, e sempre tomando o devido cuidado para não proceder a uma leitura anacrônica de seus dispositivos, os quais exigem uma leitura conforme a Constituição de 1988, não se pode negar suas características biocêntricas, na medida em que protegeu os animais enquanto vida, importantes por si próprios.

O Direito Animal brasileiro não pode prescindir desse importante e histórico instrumento normativo. Trata-se de fonte formal atual do seu ordenamento jurídico.

Interessante perceber que os que chamaram o Decreto 24.645 de "Lei Áurea" dos animais, talvez sequer tivessem em conta a real dimensão dessa expressão.

Mas é possível dizer que a Lei Áurea dos Animais inaugurou e fortaleceu um movimento social amplo, que se utilizou dos meios de comunicação social disponíveis à época, para levantar a discussão, despertar e colocar em xeque o regime de completa submissão e crueldade ao qual os animais não-humanos estavam, e ainda estão, diariamente, submetidos.

\section{Notas de fim}

1 É comum citar como primeira lei de Direito Animal no Brasil o Decreto 16.590/1924, assinado pelo Presidente Arthur Bernandes, que regulamentava as casas de diversões públicas, o qual, em seu art. 50, proibia licença para "corridas de touros, garraios, novilhos, brigas de galo e canários e quaisquer outras diversões desse gênero que causem sofrimento aos animais." (LEVAI, Laerte Fernando. Direito dos animais. 2 ed. Campos do Jordão: Editora Mantiqueira, 2004). No entanto, o Decreto 24.645/1934 se sobressai como a primeira norma jurídica geral, aplicável a todos os animais e destinada exclusivamente a isso. Por essa razão, esse segundo Decreto merece a consagração como primeira lei do Direito Animal brasileiro, o qual, como se verá, ainda continua em vigor.

2 Fontes materiais do direito "são as formadas pelos fenômenos sociais e pelos elementos extraídos da realidade social, das tradições e dos ideais dominantes, que contribuem para formar o conteúdo ou a matéria das regras jurídicas, isto é, das fontes formais do direito." (GUSMÃO, Paulo Dourado de. Introdução ao estudo do direito. 14 ed. Rio de Janeiro: Fosense, 1990. p. 130).

3 Sobre a autonomia científica do Direito Animal: SILVA, Tagore Trajano de Almeida. Direito animal e ensino jurídico: formação e autonomia de um saber pós-humanista. Salvador: Evolução, 2014. 
4 As evidências sobre a senciência dos animais não-humanos já foram objeto de contemporâneas pesquisas empíricas, afastando a concepção cartesiana do animal-máquina (DESCARTES, René. Discurso do método. Porto Alegre: L\&PM, 2009. p. 79-99); sobre o tema, consultar FELIPE, Sonia. Por uma questão de princípios: alcance e limites da ética de Peter Singer em defesa dos animais. Florianópolis: Fundação Boiteux, 2003. p. 53-62. Segundo a Declaração de Cambridge sobre a Consciência (2012) - elaborado por neurocientistas, neurofarmacologistas, neurofisiologistas, neuroanatomistas e neurocientistas computacionais cognitivos reunidos na Universidade de Cambridge -, "A ausência de um neocórtex não parece impedir que um organismo experimente estados afetivos. Evidências convergentes indicam que os animais não humanos têm os substratos neuroanatômicos, neuroquímicos e neurofisiológicos de estados de consciência juntamente como a capacidade de exibir comportamentos intencionais. Consequentemente, o peso das evidências indica que os humanos não são os únicos a possuir os substratos neurológicos que geram a consciência. Animais não humanos, incluindo todos os mamíferos e as aves, e muitas outras criaturas, incluindo polvos, também possuem esses substratos neurológicos." Conferir o texto original, em inglês, disponível em <http://fcmconference.org/img/CambridgeDeclarationOnConsciousness.pdf>. Acesso em: 4. abr. 2018.

5 A propósito, consultar: MAROTTA, Clarice Gomes. Princípio da dignidade dos animais: reconhecimento jurídico e aplicação. Belo Horizonte: Editora D’Plácido, 2019.

6 Sobre a epistemologia e as fontes formais do Direito Animal brasileiro consultar: ATAIDE JUNIOR, Vicente de Paula. Introdução ao Direito Animal brasileiro. Revista Brasileira de Direito Animal. Salvador, V. 13, n. 3, p. 48-76, set.-dez. 2018. p. 48-76.

$7 \quad$ Numa rápida incursão nos clássicos manuais de Direito Processual Civil, nada se encontrou a respeito da capacidade processual dos animais em Chiovenda, Carnelutti e Liebman. No Brasil, também nada foi encontrado em José Frederico Marques, Celso Agrícola Barbi, Ovídio Araújo Baptista da Silva, Moacyr Amaral Santos, Ernane Fidélis dos Santos, Humberto Theodoro Júnior, Cândido Rangel Dinamarco, Vicente Greco Filho, Arruda Alvim, Luiz Rodrigues Wambier e Eduardo Talamini, Luiz Guilherme Marinoni, Sérgio Cruz Arenhart e Daniel Mitidiero, Elpídio Donizetti e Daniel Amorim Assumpção Neves. Fredie Didier Júnior, ao menos até a 12a edição de seu Curso de direito processual civil: teoria geral do processo e processo de conhecimento (V. 1. Salvador: Juspodivm, 2010), negava expressamente a capacidade de ser parte ao morto e aos animais (p. 233). O mesmo se verifica na monografia Pressupostos processuais e condições da ação: o juízo de admissibilidade do processo, ao menos na edição de 2005 (São Paulo: Saraiva, 2005, p. 113). No entanto, em edições posteriores do Curso, essas negativas desapareceram, o que faz transparecer que o processualista baiano não mais está convencido desse impedimento peremptório.

8 A Conferência de Estocolmo, de 1972, normalmente é apontada, no plano internacional, como o marco inicial do desenvolvimento do Direito Ambiental (SARLET, Ingo Wolfgang, FENSTERSEIFER. Direito constitucional ambiental. 5ed. São Paulo: RT, 2017. p. 39).

9 Ainda que não recorra à categoria dos direitos, o livro de Peter Singer, Animal Liberation, de 1975, é considerado o marco das discussões ético-filosóficas envolvendo animais humanos e animais não-humanos.

10 Mais informações sobre a história da União Internacional Protetora dos Animais, consultar: <http://www.uipa.org.br/historia/>; também, com outras informações e um 
alentado acervo de fotografias de época sobre a UIPA, consultar: <http://www.saopauloantiga.com.br/uipa/>. Acesso em: 15 jul. 2019.

11 OSTOS, Natascha Stefania Carvalho de. União Internacional Protetora dos Animais de São Paulo: práticas, discursos e representações de uma entidade nas primeiras décadas do século XX. Revista Brasileira de História. São Paulo, v. 37, n. 75, 2017. p. 302.

12 O ESTADO DE S. PAULO. Proteção aos animais: um memorial da União Internacional Protetora dos Animais ao chefe do governo provisório. São Paulo, 4 de maio de1934, p. 5.

13 Trata-se do Governo Provisório instituído após a Revolução de 1930, liderada pelos Estados de Minas Gerais, Paraíba e Rio Grande do Sul, que culminou com a deposição do então Presidente Washington Luís e impediu a posse do Presidente eleito Júlio Prestes. Segundo o art. 1 o do Decreto 19.398, de 11 de novembro de 1930, assinado por Getúlio Vargas, Chefe desse novo governo, "O Governo Provisório exercerá discricionariamente, em toda sua plenitude, as funções e atribuições, não só do Poder Executivo, como também do Poder Legislativo, até que, eleita a Assembléia Constituinte, estabeleça está a reorganização constitucional do país".

14 Segundo informações obtidas em contato com a Dra. Vanice Orlandi, Presidente da UIPA, a entidade já havia buscado aprovar o texto do decreto por quatro vezes como lei municipal, sem sucesso. Todavia, em razão do grande lapso temporal entre as tentativas indicadas (1912, 1914, 1922 e 1929) e a aprovação em 1934, é pouco provável que se trate, em todas as tentativas, do mesmo texto que acabou por ser convertido no Decreto 24.645. Seguindo o método de pesquisa utilizado neste trabalho (busca no Acervo Online do Jornal o Estado de S. Paulo, na hemeroteca da Biblioteca Nacional e no Sistema SIAN do Arquivo Nacional), foram procedidas buscas dos projetos de lei apresentados, em 1912 por Francisco Portela, em 1924 pelo Deputado Luiz de Araújo, em 1922 pelo Senador Abdias Neves e em 1929 pelo parlamentar Graccho Cardoso, sem, todavia, retorno de nenhum resultado acerca dos projetos indicados.

15 OSTOS, Natascha Stefania Carvalho de. União Internacional Protetora dos Animais de São Paulo: práticas, discursos e representações de uma entidade nas primeiras décadas do século XX. p. 305.

16 Para compreender essa admiração, é de se registrar, conforme consta da história da UIPA (http://www.uipa.org.br/historia/), que "Aos 30 de maio de 1895, constituiu-se a primeira Diretoria da UIPA, cujo presidente era Ignácio Wallace da Gama Cochrane, descendente de nobres ingleses, Superintendente das Obras Públicas de São Paulo, Senador da República, fundador do Instituto Pasteur e da Companhia Telefônica de São Paulo. Cochrane foi deputado provincial em São Paulo e deputado geral, em cujo mandato Ihe coube referendar a Lei Áurea." 17 As guerras anglo-boers foram dois confrontos armados na Cidade do Cabo, na África do Sul, que opuseram os colonos de origem holandesa e francesa - os chamados bôeres - ao exército britânico, que pretendia se apoderar das minas de diamante e ouro, recentemente encontradas naquele território. Em consequência das guerras, os bôeres ficaram sob o domínio britânico, com a promessa de autogoverno. A primeira guerra se deu entre 1880 e 1881 e a segunda $\quad 1899$ entre $1902 . \quad$ Disponível em: <https://pt.wikipedia.org/wiki/Guerra_dos_B\%C3\%B4eres> Acesso em: 10 jul. 2019.

18 Tradução da inscrição do "Horse Monument", em Porth Elizabeth, África do Sul. No original: "The greatness of a nation consists not so much in the number of its people or the extent of its territory as in the extent and justice of its compassion. Erected by public 
subscriptionin recognition of the services of the gallant animals which perished in the anglo boer war 1899-1902."

19 Nesse sentido, consta em <http://www.uipa.org.br/historia/>.

20 LEVAI, Laerte Fernando. A luta pelos direitos animais no Brasil: passos para o futuro.

Revista Brasileira de Direito Animal, Salvador, v. 7, n.10, jan.-jun. 2012. p. 184.

21 Edna Cardozo Dias chegou a publicar que a inspiração do Decreto teria sido do próprio Ministro Juarez Távora (DIAS, Edna Cardozo. A tutela jurídica dos animais. Belo Horizonte, Mandamentos, 2000, p. 155), mas, posteriormente, apontou a UIPA como autora da iniciativa (DIAS, Edna Cardozo. A defesa dos animais e as conquistas legislativas do movimento de proteção animal no Brasil. Revista de Direito Ambiental, v. 2, n. 2, 2007. p. 157).

22 BRASIL. Coleção das Leis da República dos Estados Unidos do Brasil, atos do Governo Provisório, v. 4, 1934. p. 720.

23 A Constituição de 1934 foi promulgada logo após, em 16 de julho. É importante registrar que os Decretos desse primeiro período da Era Vargas, editados com força de Lei Ordinária, disciplinaram vários setores da ordem jurídica nacional. Com destaque, continua a vigorar até hoje, sem nenhuma revogação expressa ou tácita, o Decreto 20.910/1932, que disciplina a prescrição quinquenal em favor da Fazenda Pública.

24 BRASIL. Decreto 24.645 de 10 de julho de 1934. Estabelece medidas de proteção aos animais. Disponível em: <http://www2.camara.leg.br/legin/fed/decret/1930-1939/decreto24645-10-julho-1934-516837-norma-pe.html>. Acesso em: 23 out. 2018.

25 CORREIO PAULISTANO. União Internacional Protectora dos Animaes, São Paulo, n. 24017, 12 de julho de 1934. p. 7.

26 BENJAMIN, Antônio Herman de Vasconcellos. A natureza no direito brasileiro: coisa, sujeito ou nada disso. Caderno jurídico da Escola Superior do Ministério Público do Estado de São Paulo. a. 1, v. 1. n. 02, São Paulo, Jul. 2001. p. 155.

27 BRASIL. Decreto-lei 23.672 de 2 de janeiro de 1934. Approva o Código de Caça e Pesca que com este baixa. Disponível em: <http://www2.camara.leg.br/legin/fed/decret/19301939/decreto-23672-2-janeiro-1934-498613-publicacaooriginal-1-pe.html>. Acesso em: 25 nov. 2018.

28 OSTOS, Natascha Stefania Carvalho de. União Internacional Protetora dos Animais de São Paulo: práticas, discursos e representações de uma entidade nas primeiras décadas do século XX. p. 305.

29 MEDEIROS, Fernanda Luiza Fontoura de; HESS, Giovana Albo. Proteção jurídica aos animais no Brasil: reflexões entre o decreto no 24.645/34 e o projeto de lei do Senado federal no 351/15. Revista de Biodireito e Direito dos animais. Brasília, v. 2, n. 1, p. 20-35, jan.-jun. 2016. p. 22.

30 MEDEIROS, Fernanda Luiza Fontoura de; HESS, Giovana Albo. Proteção jurídica aos Animais no Brasil: reflexões entre o decreto no 24.645/34 e o projeto de lei do Senado federal no 351/15. p. 23.

31 MEDEIROS, Fernanda Luiza Fontoura de; HESS, Giovana Albo. Proteção jurídica aos Animais no Brasil: reflexões entre o decreto no 24.645/34 e o projeto de lei do Senado federal no 351/15, p. 23; ATAIDE JUNIOR, Vicente de Paula. Introdução ao Direito Animal brasileiro. p. 55 .

32 Art. 2으, §3ㅇ․ “Os animais serão assistidos em juízo pelos representantes do Ministério Público, seus substitutos legais e pelos membros das sociedades protetoras de animais". 
33 Atualmente, a Lei 5.197/1967, em seu art. 1ํ, estabelece que "Os animais de quaisquer espécies, em qualquer fase do seu desenvolvimento e que vivem naturalmente fora do cativeiro, constituindo a fauna silvestre, bem como seus ninhos, abrigos e criadouros naturais são propriedades do Estado, sendo proibida a sua utilização, perseguição, destruição, caça ou apanha." [grifo nosso].

34 Adota-se esse nomen juris para o crime do art. 32 da Lei 9.605/1998 para afastar a ideia, já ultrapassada, de que se trata de crime ambiental a tutelar o meio ambiente, o equilíbrio ambiental ou a coletividade. A vítima desse crime é o próprio animal. O bem jurídico penalmente tutelado é a dignidade animal (SANTOS, Cleópas Isaías. Experimentação animal e direito animal: o crime de crueldade e maus-tratos à luz da teoria do bem jurídico. Curitiba: Juruá, 2015. p 123) ou mesmo a vida e o bem-estar animal (TEIXEIRA NETO, João Alves. Tutela penal dos animais: uma compreensão onto-antropológica. Porto Alegre: Livraria do Advogado Editora, 2017. p. 181-182).

35 BENJAMIN, Antônio Herman Vasconcellos. A natureza no direito brasileiro: coisa, sujeito ou nada disso. p. 155.

36 Das 55 publicações referentes ao Decreto levantadas na pesquisa deste trabalho, 17 (30,9\% do total de notícias analisadas) são publicações, republicações e divulgações do Decreto, realizadas pela UIPA e por outras entidades de proteção aos animais ao redor do país. Os registros apontam que os esforços de propagação do conteúdo não se limitaram ao eixo sulsudeste, mas atingiram as mais diversas regiões do Brasil.

37 CORREIO PAULISTANO. A proteção aos animaes no Brasil, São Paulo, ano LXXXIV, n. 25.206, 13 de maio de 1938, p. 12.

38 DIÁRIO DA TARDE. União Internacional Protectora dos Animaes, Curitiba, n. 11.907, 30 de outubro de 1934. p.7.

CORREIO PAULISTANO. A proteção aos animais no Brasil, São Paulo, ano LXXXIV, n. 25.206, 13 de maio de 1938. p. 12.

39 OSTOS, Natascha Stefania Carvalho de. União Internacional Protetora dos Animais de São Paulo: práticas, discursos e representações de uma entidade nas primeiras décadas do século XX, p. 307.

40 LEVAI, Laerte Fernando. Direito dos animais. p. 30.

41 O material já publicado, principalmente em língua inglesa, sobre a Filosofia e Ética animal é inesgotável. Mas dois autores - e duas obras - costumam ser indicados como os representantes dos principais movimentos dentro da ética animal: o benestarismo, capitaneado por Peter Singer, a partir do seu livro Libertação animal (Porto Alegre, São Paulo: Editora Lugano, 2004), de 1974; e o abolicionismo, dirigido por Tom Regan, a partir do seu livro The case for animal rights (Berkeley: University of California Press, 1983), de 1983. Em língua portuguesa, vale a pena consultar a obra $\mathrm{A}$ hora dos direitos dos animais, de Fernando Araújo (Coimbra: Almedina, 2003), que aborda as principais discussões filosóficas sobre os animais, com ampla varredura de tudo o que se escreveu sobre o assunto até então, bem como a obra Direito dos animais: fundamentação e novas perspectivas (Porto Alegre: Sérgio Antonio Fabris Editor, 2008), de Daniel Braga Lourenço, que também procede a um alentado levantamento das premissas filosóficas do Direito Animal.

42 GORDILHO, Heron José de Santana e SILVA, Tagore Trajano de Almeida. Animais em juízo: direito, personalidade jurídica e capacidade processual. Revista de direito ambiental. V. 65, p. 333-363, São Paulo: RT, jan. 2012; SILVA, Tagore Trajano de Almeida. Capacidade de ser 
parte dos animais não-humanos: repensando os institutos da substituição e representação processual. Revista brasileira de direito animal. Ano 4, n. 05, p. 323-352, Salvador: Evolução Editora, jan.-dez. 2009; STONE, Christopher D. Should trees have standing? Toward legal rights for natural objects. Southern California law review. V. 45, p. 450, 1972; SUNSTEIN, Cass R. Can animals sue? In: SUNSTEIN, Cass R., NUSSBAUM, Martha C. (coords.). Animal rights: current debates and new directions. New York: Oxford University Press, p. 251-262, 2004.

43 LEVAI, Laerte Fernando. Direito dos animais, p. 31; RODRIGUES, Danielle Tetü. O direito \& os animais: uma abordagem ética, filosófica e normativo. 2 ed, Curitiba: Juruá, 2012. p. 66.

44 É interessante aqui confrontar essa admiração com os levantamentos sobre a relação entre os seres humanos e o mundo natural, especialmente na Europa dos séculos XV e XVIII, feitos em THOMAS, Keith. O homem e o mundo natural: mudanças de atitude em relação às plantas e aos animais. Tradução de João Roberto Martins Filho. São Paulo: Companhia das Letras, 1998.

45 REINO UNIDO. Protection of Animals Act 1911 (Chapter 271 and 2 Geo 5). Disponível em: <https://www.legislation.gov.uk/ukpga/Geo5/1-2/27>. Acesso em: 25 out. 2018.

46 Tradução livre de partes dos texto original, quais sejam: "1.-(I) If any person- (a) shall cruelly beat, kick, ill-treat, over-ride, over-drive, over-load; torture, infuriate, or terrify any animal, or, shall cause or procure, or, being the owner, permit any animal to be so used, or shall, by wantonly or unreasonably doing or omitting to do any act, or causing or procuring the commission or omission of any act, cause any unnecessary suffer ing, or, being the owner, permit any unnecessarysuffering to be so caused to any animal ; or (b) shall convey or carry, or cause or procure, or, being the owner, permit to be conveyed or carried, any animal in such manner or position as to cause that animal any unnecessary suffering ; or (c) shall cause, procure, or assist at the fighting or baiting of any animal; or shall keep, use, manage, or act or assist in the management of, any premises or place for the purpose, or partly for the purpose, of fighting or baiting any animal, or shall permit any premises or place to be so kept, managed, or used, or shall receive, or cause or procure any person to receive, money for the admission of any person to such premises or place; or (d) shall wilfully, without any reasonable cause or excuse, administer, or cause or procure, or being the owner permit, such administration of, any poisonous or injurious drug or substance to any animal, or shall wilfully, without any reasonable cause or excuse, cause any such substance to be taken by any animal; or (e) shall subject, or cause or procure, or being the owner permit, to be subjected, any animal to any operation which is performed without due care and humanity; such person shall be guilty of an offence of cruelty within the meaning of this Act, and shall be liable upon summary conviction to a fine not exceeding twenty-five pounds, or alternatively, or in addition thereto, to be imprisoned, with or without hard labour, for any term not exceeding six months."

47 No original: 7.-(1) Any person who impounds or confines, or causes to be impounded or confined, any animal in any pound shall, while the animal is so impounded or confined, supply it with a sufficient quantity of wholesome and suitable food and water, and, if he fails to do so, he shall be liable upon summary conviction to a fine not exceeding five pounds. (2) If any animal is impounded or confined in any pound and is without sufficient suitable food or water for six successive hours, or longer, any person may enter the pound for the purpose of supplying the animal therewith.

$48 \quad$ ARGENTINA. Lei 2.786 de 25 de julho de 1891. Buenos Aires, 1891. 
$49 \quad 0$ art. 1으 da Lei argentina traz a previsão de multa, mas, diferentemente do art. 2ㅇ do Decreto 24.645/1934, não prevê nenhum tipo de prisão em caso de maus-tratos dos animais: "ARTíCULO 1.- Declárase actos punibles los malos tratamientos ejercitados con los animales, y las personas que los ejerciten sufrirán una multa de dos a cinco pesos, o en su defecto arresto, computándose dos pesos por cada día."

50 FRANÇA. Loi du 2 juillet 1850 relative aux mauvais traitements exercés envers les animaux domestiques. 1850. Disponível em: <http://www.theatreduchenevert.com/wpcontent/uploads/2016/07/Loi_grammont-1850.pdf >. Acesso em: 25 out. 2018. Heron José da Santana Gordilho salienta que a proibição de crueldade com animais domésticos da "Lei Grammont" preocupava-se com a sensibilidade humana e não com o sofrimento dos animais. Nada obstante, foi a primeira a proibir maus-tratos na França (GORDILHO, Heron José de Santana. Abolicionismo animal. Salvador: Evolução Editora, 2008. p. 63).

51 "Art. 2‥ Aquele que, em lugar público ou privado, aplicar ou fizer aplicar maus tratos aos animais, incorrerá em multa de $20 \$ 000$ a 500\$000 e na pena de prisão celular de 2 a 15 dias, quer o delinquente seja ou não o respectivo proprietário, sem prejuízo da ação civil que possa cabe."

52 "Art. 15. Em todos os casos de reincidência ou quando os maus tratos venham a determinar a morte do animal, ou produzir mutilação de qualquer dos seus órgãos ou membros, tanto a pena de multa como a de prisão serão aplicadas em dobro."

53 ITÁLIA. Codice Penale, Roma: Stamperia Reale, 1889.

54 No original: "art. 491. Chiunque incrudelisce verso animali o, senza necessità, li matatta, ovvero li costringe a fatiche manifestamente ecessive, è punito con l'ammenda sino a lire cento.Alla stessa pena soggiace colui il quale, anche per solo fine scientifico o didattico, ma fuori dei luogui destinati all'insegnamento sottipone animali a esperimenti tali da destare ribrezzo."

55 CORREIO PAULISTANO. A proteção aos animais no Brasil, São Paulo, ano LXXXIV, n. 25.206, 13 de maio de 1938. p. 12.

56 O ESTADO DE SÃO PAULO. Sociedade Paulista Protectora dos Animaes, São Paulo, 05 de agosto de 1938.

57 O JORNAL, Rio de Janeiro, 16 de setembro de 1938, n. 05908, p. 8., O JORNAL, Rio de Janeiro, n. 0909, p.10 e CORREIO DA MANHÃ, Rio de Janeiro, n. 13259, p. 34.

58 O JORNAL. Protecção aos animais de tração, Florianópolis/SC, n. 06251, 13 de agosto de 1934. p. 1.

59 O pedido provavelmente foi formulado com base no artigo 16 do Decreto: "Art.16 A Polícia prestará apoio ao Abrigo de Proteção aos animais para cumprir o Decreto 24645."

60 JORNAL DO BRASIL. Nada de touradas. Rio de Janeiro, n. 0284, 04 dezembro 1938. p. 5.

61 A MANHÃ. Touradas, mas sem sangue. Rio de Janeiro, n. 0276, 06 de junho de 1950. p.

1.

62 A MANHÃ. Rejeitado o projeto das touradas. Rio de Janeiro, n. 0830. p. 8.

63 Proibição da farra do boi pela jurisdição constitucional: STF, 2a Turma, Relator Ministro Francisco Rezek, Acórdão lavrado pelo Ministro Marco Aurélio, julgado em 03/6/1997, publicado em 13/3/1998.

64 "VAQUEJADA - MANIFESTAÇÃO CULTURAL - ANIMAIS - CRUELDADE MANIFESTA PRESERVAÇÃO DA FAUNA E DA FLORA - INCONSTITUCIONALIDADE. A obrigação de o Estado garantir a todos o pleno exercício de direitos culturais, incentivando a valorização e a difusão

70 | Revista Brasileira de Direito Animal, e -issn: 2317-4552, Salvador, volume 15, n. 02, p.47-73, Mai - Ago 2020 
das manifestações, não prescinde da observância do disposto no inciso VII do artigo 225 da Carta Federal, o qual veda prática que acabe por submeter os animais à crueldade. Discrepa da norma constitucional a denominada vaquejada." (STF, Pleno, ADI 4983, Relator Ministro MARCO AURÉLIO, julgado em 06/10/2016, publicado em 27/04/2017).

65 O ESTADO. Boi-na-vara. Santa Catarina, n. 06348, 14 de dezembro de 1934. p. 8.

66 O ESTADO DE S. PAULO. Farra do boi ou tortura do boi? São Paulo, 28 de abril de 1988, p. 38. Já em 1997, O Estado de S. Paulo publicou carta com 165 assinaturas, criticando a realização, sob rótulo de "tradição cultural e religiosa", da farra do boi em Santa Catarina. Na opinião dos assinantes, tanto o Decreto 24645/1934, quanto o artigo 225, §1으, inciso VII, da Constituição Federal, proíbem a prática (O Estado de S. Paulo. Farra do boi. São Paulo, 07 de março de 1997). Poucos meses depois, o STF julgou a farra do boi "procedimento discrepante da norma constitucional", já que a norma do inciso VII do artigo 225 veta a crueldade contra animais (STF, 2a Turma, Relator Ministro Francisco Rezek, Acórdão lavrado pelo Ministro Marco Aurélio, julgado em 03/6/1997, publicado em 13/3/1998).

67 GAZETA DE NOTÍCIAS. Denunciado por haver morto um animal doméstico. Rio de Janeiro, n. 14.645, 10 de novembro de 1934. p. 5.

68 CORREIO PAULISTANO. Parecer do 10 Promotor Público num caso de prescripção de acção penal. São Paulo, n. 25493, 18 de abril de 1939. p. 17.

69 O ESTADO DE S. PAULO. Maus tratos a animaes. São Paulo, 19 de abril de 1939. p. 12.

70 DIÁRIO CARIOCA. Homicídio ou canicídio. Rio de Janeiro, n. 02988, 09 de março de 1938. p. 6. Não foram encontradas outras notícias que relatem o desfecho do caso.

71 SÃO PAULO. Diário Oficial. "Botucatú", 15 de janeiro de 1942. p. 32.

72 A insuficiência normativa sempre induziu os advogados e juristas a reelaborarem conceitos jurídicos para ajustá-los às necessidades protetivas de uma época. Foi o caso, por exemplo, da doutrina brasileira do habeas corpus, conforme preconizado por Ruy Barbosa, para a defesa de direitos para além dos relativos ao ir e vir. Sobre o tema, consultar: SOUZA, Luiz Henrique Boselli de. A doutrina brasileira do habeas corpus e a origem do mandado de segurança: análise doutrinária de anais do Senado e da jurisprudência histórica do Supremo Tribunal Federal. Revista de Informação Legislativa, Brasília, a. 45 n. 177, jan./mar. 2008.

73 CORREIO DO PARANÁ. Animaes sem proteção. Curitiba, n. 00673, 23 de agosto de 1934, p. 3.

74 CORREIO DO PARANÁ. Proteção aos animais. Curitiba, n. 00677, 28 de agosto de 1934. p. 6.

75 ARTHUR ERNST EWERT (HERRY BERGER). Verbete Biográfico. Centro de Pesquisa e Documentação de História Contemporânea do Brasil - CPDOC, Fundação Getúlio Vargas. Disponível em: <http://www.fgv.br/cpdoc/acervo/dicionarios/verbete-biografico/arthur-ernstewert>. Acesso em: 30 out. 2018.

76 PINTO, Sobral, 1979 apud NEVES, Daniel Monteiro. Como se defende um comunista: uma análise retórico-discursiva da defesa judicial de Harry Berger por Sobral Pinto. São João del-Rei, 2013, 226 p. Dissertação (Mestrado em Letras) - Pós-Graduação em Letras da Universidade Federal de São João del-Rei. p. 151.

77 A NOITE. Condemnado pela morte do cavalo. Rio de Janeiro, n. 09667, 29 de janeiro de 1937. p. 3.

78 PINTO, Sobral, 1979 apud NEVES, Daniel Monteiro. Como se defende um comunista: uma análise retórico-discursiva da defesa judicial de Harry Berger por Sobral Pinto. p. 154. Em 
que pese a argumentação formulada por Sobral Pinto, Berger permaneceu preso até 1945, quando foi anistiado, mas nunca recuperou sua sanidade física e mental.

79 NEVES, Daniel Monteiro. Como se defende um comunista: uma análise retóricodiscursiva da defesa judicial de Harry Berger por Sobral Pinto. p. 153.

80 O ESTADO DE S. PAULO. Favelados protestam contra invasões. São Paulo, 28 de julho de 1988. p. 21.

81 REGIS, Arthur Henrique de Pontes. Vulnerabilidade como fundamento pra os direitos dos animais: uma proposta pra um novo enquadramento jurídico. Brasília: Novas Edições Acadêmica, 2018. p. 70.

82 REGIS, Arthur Henrique de Pontes. Vulnerabilidade como fundamento pra os direitos dos animais: uma proposta pra um novo enquadramento jurídico. p. 70.

83 BRASIL. Decreto 11, de 18 de janeiro de 1991. Diário Oficial da União, Seção 1, 21/1/1991, Página 1513 (Publicação Original).

84 O Decreto 11/1991 também foi revogado, posteriormente, por meio do Decreto 761/1993 (DOU 20/2/1993), sem efeitos repristinatórios.

85 MENDES, Gilmar Ferreira; BRANCO, Paulo Gonet. Curso de direito constitucional. 10 ed. atual. São Paulo: Saraiva, 2015. p. 904 (e-book).

86 MELLO, Celso Antônio Bandeira de. Curso de direito administrativo. 27 ed. São Paulo: Malheiros, 2010. p. 343.

87 TÁCITO, Caio. Medidas provisórias na Constituição de 1988, Revista de Direito Público, Rio de Janeiro, p. 52-90, abr.-jun.1989.

88 MENDES, Gilmar Ferreira; BRANCO, Paulo Gonet. Curso de direito constitucional, p. 914.

89 Cf. CASTRO, João Marcos Adele y. Direito dos animais da legislação brasileira. Porto Alegre: Sergio Antônio Fabris Editor, 2006. p. 104.

90 BENJAMIN, Antônio Herman Vasconcellos. A natureza no direito brasileiro: coisa, sujeito ou nada disso. p. 155.

91 Decreto-Lei 3.688/1941, art. 64: Tratar animal com crueldade ou submetê-lo a trabalho excessivo: Pena - prisão simples, de dez dias a um mês, ou multa, de cem a quinhentos mil réis. $\S 1$ 1․ Na mesma pena incorre aquele que, embora para fins didáticos ou científicos, realiza em lugar público ou exposto ao público, experiência dolorosa ou cruel em animal vivo. § 2‥ Aplicase a pena com aumento de metade, se o animal é submetido a trabalho excessivo ou tratado com crueldade, em exibição ou espetáculo público.

92 Art. 32. Praticar ato de abuso, maus-tratos, ferir ou mutilar animais silvestres, domésticos ou domesticados, nativos ou exóticos: Pena - detenção, de três meses a um ano, e multa. $\S 1$ In Incorre nas mesmas penas quem realiza experiência dolorosa ou cruel em animal vivo, ainda que para fins didáticos ou científicos, quando existirem recursos alternativos. $§ 2$ ㅇ $\mathrm{A}$ pena é aumentada de um sexto a um terço, se ocorre morte do animal.

93 O art. 2o caput permanece vigente em relação a sua parte final, para orientar ações civis que tenham por objeto a repressão de práticas cruéis: "Aquele que, em lugar público ou privado, aplicar ou fizer aplicar maus tratos aos animais, incorrerá em multa de $20 \$ 000$ a 500\$000 e na pena de prisão celular de 2 a 15 dias, quer o delinquente seja ou não o respectivo proprietário, sem prejuízo da ação civil que possa caber" [grifo nosso].

94 O Conselho Federal de Medicina Veterinária (CFMV) editou a Resolução 1236, de 26 de outubro de 2018, definindo e caracterizando crueldade, abuso e maus-tratos contra animais 
vertebrados, e dispondo sobre a conduta de médicos veterinários e zootecnistas. Evidentemente, trata-se de ato normativo de natureza corporativa, a orientar a conduta dos profissionais submetidos a sua fiscalização do órgão público. Para fins de definição criminal de crueldade, abuso e maus-tratos a animais deve preponderar, para fins de enquadramento no art. 32 da Lei 9.605/1998, os conceitos e definições estabelecidas em Lei, no caso, o vigente Decreto 24.645/1934.

95 João Marcos Adele y Castro indica que o art. 3o do Decreto 24.645/34 explicita a disposição do art. 32 da Lei 9.605/98, na medida em que refere trinta e uma hipóteses que podem ser consideradas maus-tratos (CASTRO, João Marcos Adele y. Direito dos animais da legislação brasileira. p. 104).

96 PIERANGELI, José Henrique. Parecer em direito penal ambiental. Justitia, São Paulo: Procuradoria Geral de Justiça; Associação Paulista do Ministério Público, v. 60, n. 181-184, p. 38-59, jan.-dez. 1998. p. 56.

97 LEVAI, Laerte Fernando. Direito dos animais, p. 30.

98 ATAIDE JUNIOR, Vicente de Paula. Introdução ao Direito Animal brasileiro. p. 55.

99 STF, Plenário, ADIn 1856 MC, Relator Ministro CARLOS VELLOSO, julgado em 03/09/1998, DJ 22/09/2000.

100 STJ, 2a Turma, REsp 1115916/MG, Relator Ministro HUMBERTO MARTINS, julgado em 01/09/2009, DJe 18/09/2009. 